\title{
Design and evaluation of novel 4-anilinoquinolines and quinazolines EGFR inhibitors in lung cancer and chordoma
}

\author{
Christopher R. M. Asquith ${ }^{\mathrm{a}, \mathrm{b},}$, Kaitlyn A. Maffuid ${ }^{\mathrm{c}}$, Tuomo Laitinen ${ }^{\mathrm{d}}$, Chad D. Torrice ${ }^{\mathrm{c}}$, Graham J. \\ Tizzard $^{\text {, }}$, Carla Alamillo-Ferrere, Karl M. Koshlap ${ }^{\text {f, Daniel J. Crona }}{ }^{\mathrm{c}, \mathrm{g}}$, William J. Zuercher ${ }^{\mathrm{b}, \mathrm{g}, *}$ \\ ${ }^{a}$ Department of Pharmacology, School of Medicine University of North Carolina at Chapel Hill, Chapel Hill, NC 27599, USA \\ ${ }^{b}$ Structural Genomics Consortium, UNC Eshelman School of Pharmacy, University of North Carolina at Chapel Hill, Chapel Hill, NC, 27599, USA \\ ${ }^{c}$ Division of Pharmacotherapy and Experimental Therapeutics, UNC Eshelman School of Pharmacy, University of North Carolina at Chapel Hill, Chapel Hill, \\ NC 27599, USA. \\ ${ }^{d}$ School of Pharmacy, Faculty of Health Sciences, University of Eastern Finland, 70211 Kuopio, Finland; \\ eSchool of Chemistry, University of Manchester, Manchester, M13 9PL, United Kingdom. \\ ${ }^{f} U N C$ Eshelman School of Pharmacy, University of North Carolina at Chapel Hill, Chapel Hill, North Carolina, USA \\ ${ }^{g}$ Lineberger Comprehensive Cancer Center, University of North Carolina at Chapel Hill, Chapel Hill, NC 27599, USA
}

\section{ARTICLE INFO}

\section{ABSTRACT}

Article history:

Received

Revised

Accepted

Available online

Keywords:

Epidermal Growth Factor Receptor (EGFR)

4-anilinoquinoline

4-anilinoquinazoline

Non-small cell lung cancer (NSCLC)

EGFR Asp855 (D855)

Chordoma
Cancer is the second leading cause of death globally and is responsible for an estimated 9.6 million deaths in $2018 .{ }^{1}$ Kinases have been successfully utilized as drug targets for the past 30 mainly cancer indications. ${ }^{2}$ One target that has been intensely studied is epidermal growth factor receptor (EGFR). The inhibitors gefitinib and erlotinib provide significant clinical benefit in patients diagnosed with non- small cell lung cancer<smiles>C#Cc1cccc(Nc2ncnc3cc(OCCOC)c(OCCOC)cc23)c1</smiles>

Erlotinib

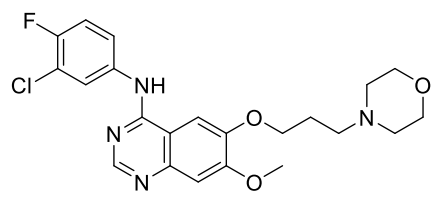

Gefitinib<smiles>CS(=O)(=O)CCNCc1ccc(-c2ccc3ncnc(Nc4ccc(OCc5cccc(F)c5)c(Cl)c4)c3c2)o1</smiles>

Lapatinib years, with 38 kinase inhibitors approved by the FDA to date for

Figure 1. Example structures of clinical EGFR quinazolines.

(NSCLC) (Fig. 1). ${ }^{3-4}$ The subsequent development of lapatinib as a dual EGFR and Her2 inhibitor has extended the clinical utility of
EGFR inhibitors to the treatment of Her2 positive breast cancers (Fig. 1). ${ }^{5}$

Therapeutic intervention in the EGFR pathway is not limited to NSCLC and breast cancer. Other cancers show sensitivity to EGFR inhibitors. ${ }^{6}$ These include chordomas, which are rare tumors arising along the bones of the central nervous system and spine. ${ }^{7}$ These tumors are a significant challenge to treat and radical surgery is the preferred course of treatment. ${ }^{7-8}$ EGFR and its ligand, EGF, are highly expressed in chordomas, and copy number gains of EGFR occur in $40 \%$ of chordomas. A number of EGFR inhibitors have been identified that are active in cellular models of chordoma, and afatinib is now undergoing phase 2 clinical trials for treatment of chordoma. ${ }^{9-12}$

Kinase inhibitors commonly have off-targets across the kinome that confound the ability to accurately define the mechanism of action leading to induced phenotypes of interest. ${ }^{13}$ The 4-anilinoquinoline and quinazolines scaffold have demonstrated a range of activity profiles across the kinome from highly selective to broadly promiscuous. ${ }^{14-15}$ We were intrigued by lapatinib's narrower spectrum kinome profile in addition to the longer chained aniline substituent that reduces common off-target activity by accessing a back pocket in the EGFR ATP-binding site. One significant tractable off-target is cyclin-G-associated kinase (GAK) which is frequently observed to bind 4-anilino-quinoline, quinazolines and 3-cyano-quinolines. ${ }^{16}$ 
We first designed a small series of compounds to probe the hinge region to investigate the influence of the hinge binding moiety while maintaining the simple erlotinib aniline. To determine the effect of small subtle core modification, these compounds were docked into EGFR using the Schrödinger Maestro suite (Fig. 2). ${ }^{17}$

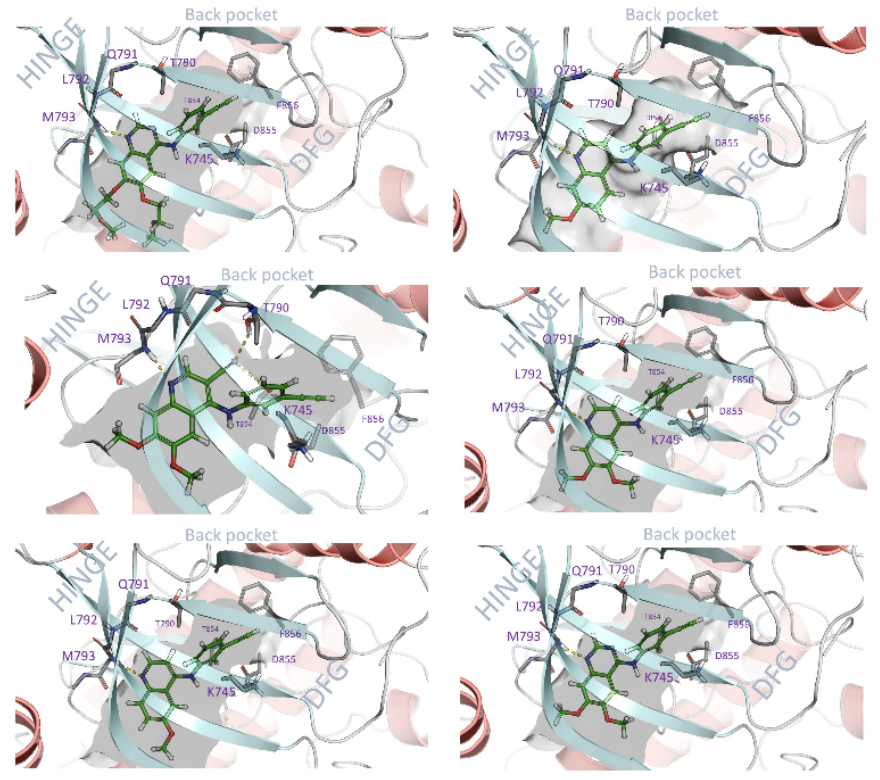

Figure 2. Examples of docked compounds (Left to right - erlotinib, 4, 7, 1, 2, 3 ) in the ATP compteative EGFR binding domain

We prepared several focused arrays of compounds to probe the structure activity relationships of the quinoline/quinazoline series. We synthesized a series of compounds (1-9, 13-15, 17-19) through nucleophilic aromatic displacement of commercially available 4chloroquin(az)olines in excellent yields (58-85\%), consistent with previous reports (Sch. 1). ${ }^{14-15,18}$

These compounds were profiled in an EGFR cellular activity assay, in addition to a lung cancer cell line and several chordoma cell lines (Tab. 1). The 6,7-dimethoxyquinolin-4-amine with the erlotinib 3-ethynylaniline (1) showed high potency in the in-cell EGFR phosphorylation assay $\left(\mathrm{IC}_{50}=270 \mathrm{nM}\right)$, as previously reported. ${ }^{19}$ The data on the chordoma cell lines (UCH-1 and UCH2 ) is also consistent with previous reports. ${ }^{19}$ The A431 lung cancer cell line showed good activity at $\mathrm{IC}_{50}=1.4 \mu \mathrm{M}$ and threefold weaker potency on WS-1 normal fibroblast cell viability. The removal of either methoxy group to form the 6-methoxy (2) or 7methoxy (3) yielded compounds with more than a 60-fold drop in EGFR in cell potency. This also led to a drop off in cellular potency in the lung cancer cell line and UCH-1, there was a double in potency in UCH-2. However, the potency values of $\mathbf{2}$ and $\mathbf{3}$ were still in the low double digit micromolar range.

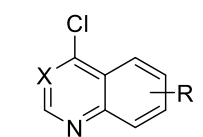

$\mathrm{X}=\mathrm{CH}, \mathrm{N}, \mathrm{C}-\mathrm{CN}$

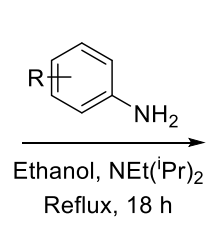

Scheme 1. General synthetic procedure
The switch to the quinazoline (4) showed a similar potency range to 1 with a slight increase in potency in A431 cells. The removal of either methoxy (5 and 6) had no impact on in cell EGFR activity but did reduce activity in all 3 cancer cell lines with no effect in WS-1. The 3-cyano quinoline hinge binder showed a marked drop off in cell EGFR activity. The 6,7-dimethoxy analog (7) showed similar potencies to the mono-methoxy quinazolines (5 and 6). It was then surprising that the removal of either methoxy (8 and 9) reduced the anti-proliferative effect seen in other analogs (7), suggesting the involvement of other targets.

With the results of the small focused series in hand, we then started to modify the aniline scaffold, with the aim of establishing an internal hydrogen bond, not only to form a pre-organized structure but also to form an interaction with Asp855 as in Figure 3. In tandem we looked at the water network in EGFR (Fig. 4) and found that by adding a methyl group to the pendent benzyl we were able to increase the ligand efficiency of our model system. ${ }^{19}$

Table 1. Results of a small series of compounds to structurally different hinge binders (1-9)<smiles>[R]c1cc2nc[X]c(Nc3cccc(C#C)c3)c2cc1[R]</smiles>

\begin{tabular}{|c|c|c|c|c|c|c|c|c|}
\hline \multirow{2}{*}{ Cmpd } & \multirow{2}{*}{$\mathbf{R}^{1}$} & \multirow{2}{*}{$\mathbf{R}^{2}$} & \multirow{2}{*}{$\mathbf{R}^{3}$} & \multirow{2}{*}{$\begin{array}{c}\text { EGFR }^{\mathrm{a}} \\
\text { IC }_{50}(\mu \mathrm{M})\end{array}$} & A431 & UCH-1 & UCH-2 & WS-1 \\
\hline & & & & & \multicolumn{4}{|c|}{$\mathrm{IC}_{50}(\mu \mathrm{M})^{\mathrm{b}}$} \\
\hline 1 & $\mathrm{OMe}$ & $\mathrm{OMe}$ & $\mathrm{CH}$ & $0.27^{\mathrm{c}}$ & 1.4 & 0.54 & 42 & 4.6 \\
\hline 2 & $\mathrm{OMe}$ & $\mathrm{H}$ & $\mathrm{CH}$ & 16 & 10 & 6.6 & 16 & $>100$ \\
\hline 3 & $\mathrm{H}$ & $\mathrm{OMe}$ & $\mathrm{CH}$ & $>20$ & 3.4 & 9.4 & 17 & $>100$ \\
\hline 4 & $\mathrm{OMe}$ & $\mathrm{OMe}$ & $\mathrm{N}$ & $0.55^{\mathrm{c}}$ & 0.85 & 0.63 & 66 & 15 \\
\hline 5 & $\mathrm{OMe}$ & $\mathrm{H}$ & $\mathrm{N}$ & 0.59 & 2.2 & 1.4 & 47 & $>100$ \\
\hline 6 & $\mathrm{H}$ & $\mathrm{OMe}$ & $\mathrm{N}$ & 0.53 & 8.0 & 1.9 & 1.2 & $>100$ \\
\hline 7 & $\mathrm{OMe}$ & $\mathrm{OMe}$ & $\mathrm{C}-\mathrm{CN}$ & $1.8^{\mathrm{c}}$ & 1.7 & 4.1 & 36 & $>100$ \\
\hline 8 & $\mathrm{OMe}$ & $\mathrm{H}$ & $\mathrm{C}-\mathrm{CN}$ & 3.5 & $>100$ & 19.6 & $>100$ & $>100$ \\
\hline 9 & $\mathrm{H}$ & $\mathrm{OMe}$ & $\mathrm{C}-\mathrm{CN}$ & 1.1 & 44 & 4.1 & 40 & $>100$ \\
\hline
\end{tabular}

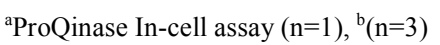


<smiles>[R]c1ccc(C(=O)OCC(=O)O)cc1</smiles>

10<smiles>[R]c1ccc(C(=O)Nc2ccc(N)cc2O)cc1</smiles>

$11-R^{1}=\operatorname{Me}(78 \%)$ $12-\mathrm{R}^{1}={ }^{\mathrm{t}} \mathrm{Bu}(71 \%)$

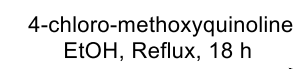

$13-R^{1}=M e, R^{2}=R^{3}=O M e$ $14-R^{1}=M e, R^{2}=O M e, R^{3}=H$ $15-R^{1}=M e, R^{2}=H, R^{3}=O M e$ $17-R^{1}={ }^{\mathrm{t}} \mathrm{Bu}, \mathrm{R}^{2}=\mathrm{R}^{3}=\mathrm{OMe}$<smiles>[R1]c1ccc(C(=O)Nc2ccc(Nc3cc[n+]([13CH3])c4cc([R])c([R])cc34)cc2O)cc1</smiles>

Scheme 2. Synthetic procedure for 13-15 and 17<smiles>Cc1ccc(C(=O)Nc2ccc(N)cc2)cc1</smiles><smiles>COc1cc2nccc(Cl)c2cc1OC</smiles>

$\mathrm{Pd}_{2}(\mathrm{dba})_{3}$ $\underset{\text { DMF, } 140{ }^{\circ} \mathrm{C}, 18 \mathrm{~h}}{\stackrel{\mathrm{XPhos}, \mathrm{Cs}_{2} \mathrm{CO}_{3}}{\longrightarrow}}$<smiles>COc1cc2nccc(Nc3ccc(NC(=O)c4ccc(C)cc4)cc3)c2cc1OC</smiles>

Scheme 3. Synthetic procedure for $\mathbf{1 6}$

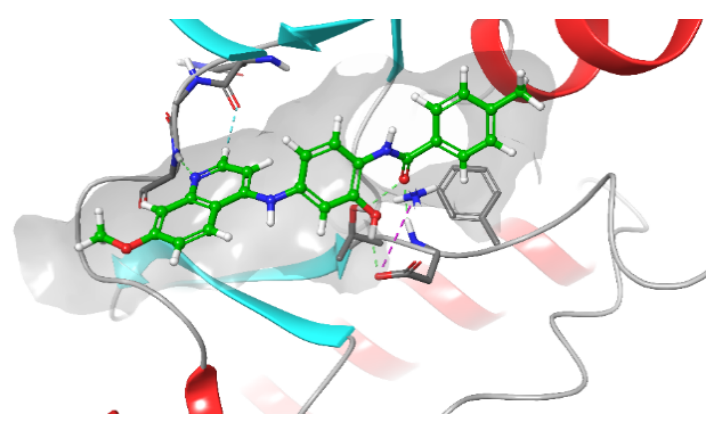

Figure 3. Docking of $\mathbf{1 5}$ with an alcohol substitution into EGFR

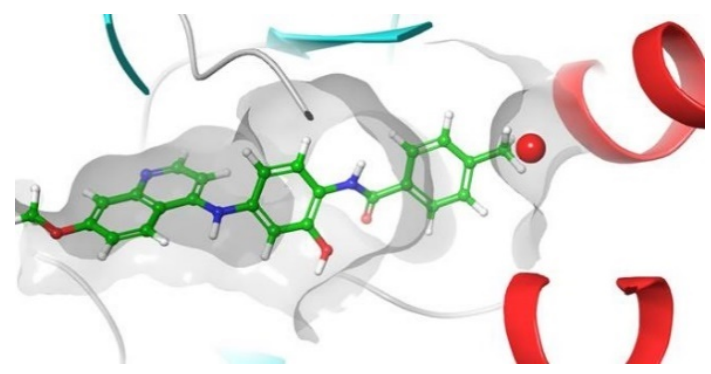

Figure 4. WaterMap simulation of $\mathbf{1 5}$ in EGFR

We prepared several additional compounds (13-18) where the anilines were not readily available as the ones in Scheme 1, following a three-step protocol from commercially available 2amino-5-nitrophenol (10) as starting material. 10 was coupled with $\mathrm{CDI}$ to furish an amide bond, followed by $\mathrm{H}_{2}$ reduction to give intermediates 11 and 12 (Sch. 2). $S_{N} A$ r reactions of intermediates 11 and 12 under reflux provided compounds 13-15 and 17 in good yields $(58-76 \%) .{ }^{18}$ The des-hydroxy compound (16) proved inaccessible via a nucleophilic aromatic displacement (even up to $150{ }^{\circ} \mathrm{C}$, DMF, DIPEA, $18 \mathrm{~h}$ ) and required Buchwald-Hartwig conditions (Sch. 3) to produce 16 in good overall yield (72\%). ${ }^{15}$

The 6,7-dimethoxyquinolin-4-amine with the lapatinib derived hydroxy amide aniline (13) showed double digit micromolar potency in the in-cell EGFR phosphorylation assay and moderate activity in the A431 cell line and good activity in both chordoma cell lines tested. Removal of one of the methoxy groups (14 and
15) had the opposite effect to the previous set (1-9) and led to an increase in activity in the chordoma cell lines with no change in the A431 anti-proliferative effect.

Interestingly our hypothesis of including the alcohol proved to be pivotal for activity, with the removal of the alcohol (16) removing the bulk of the activity previously observed in 13-15. We also considered increasing the bulk tert-butyl on the pendant benzyl (17) to more fully occupy the displaced water pocket. This only led to additional molecular weight with no potency gain compared with 13. It was surprising that the para-methyl benzylic ether substitution (18) with no alcohol showed no in-cell EGFR activity and a limited effect in A431 cells. However, in the two chordoma cell lines there was a sharp increase in activity. 18 is one of the most potent compounds seen to data with an $\mathrm{IC}_{50}$ of $330 \mathrm{nM}$ and $310 \mathrm{nM}$ for $\mathrm{UCH}-1$ and $\mathrm{UCH}-2$ respectively. This result is more impressive considering that $\mathrm{UCH}-2$ is typically less sensitive to compound treatment. However 18 does show some observed toxicity in WS-1. The removal of the benzyl in $\mathbf{1 9}$ had a similar effect to removing the alcohol in $\mathbf{1 6}$ with most activity lost, but moderate potency in A431 was still observed.

We were also interested in the conformation of $\mathbf{1 3}$ to see if there would be a rigidity imparted by the alcohol onto the pendant arm structure that was not observed in 16. The small molecule crystal structure of $\mathbf{1 3}$ was solved as a monoclinic structure with a 27:73 to the pre-organization to the internal seven membered ring system (Fig 5). ${ }^{20}$ This system would likely be more ordered, however under our crystalisation conditions the alcohol forms a $2.99 \AA$ hydrogen bond with the chloride ion. This significant electrostatic component within the lattice acts as an anchor, hindering further pre-organisation.

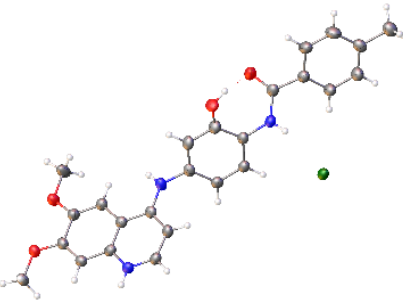

27

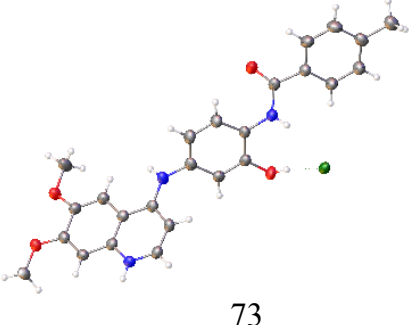

73
Figure 5. Small molecules crystal structure of $\mathbf{1 3}$ 
Table 2. Matched pair comparison of benzyloxyaniline
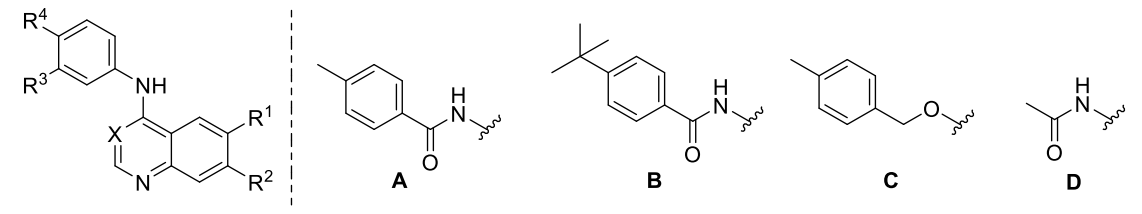

\begin{tabular}{|c|c|c|c|c|c|c|c|c|c|}
\hline Compound & $\mathbf{R}^{1}$ & $\mathbf{R}^{2}$ & $\mathbf{R}^{3}$ & $\mathbf{R}^{4}$ & $\begin{array}{c}\text { EGFR }^{\mathrm{a}} \\
\mathrm{IC}_{50}(\mathrm{uM})\end{array}$ & A431 & $\begin{array}{r}\text { UCH-1 } \\
\text { EC }\end{array}$ & $\begin{array}{l}\text { UCH-2 } \\
\text { M) }\end{array}$ & WS-1 \\
\hline 13 & $\mathrm{OMe}$ & $\mathrm{OMe}$ & $\mathrm{OH}$ & $\mathbf{A}$ & 14 & 1.6 & 1.6 & 2.4 & 1.4 \\
\hline 14 & $\mathrm{OMe}$ & $\mathrm{H}$ & $\mathrm{OH}$ & $\mathbf{A}$ & 14 & 1.8 & 0.93 & 1.4 & 1.4 \\
\hline 15 & $\mathrm{H}$ & $\mathrm{OMe}$ & $\mathrm{OH}$ & $\mathbf{A}$ & 6.3 & 1.7 & 0.49 & 0.68 & 0.86 \\
\hline 16 & $\mathrm{OMe}$ & $\mathrm{OMe}$ & $\mathrm{H}$ & $\mathbf{A}$ & $>20$ & 21 & 14 & 21 & $>100$ \\
\hline 17 & $\mathrm{OMe}$ & $\mathrm{OMe}$ & $\mathrm{OH}$ & B & 13 & 1.8 & 1.2 & $>100$ & 1.9 \\
\hline 18 & $\mathrm{OMe}$ & $\mathrm{OMe}$ & $\mathrm{H}$ & $\mathbf{C}$ & $>20$ & 1.5 & 0.33 & 0.31 & 1.1 \\
\hline 19 & $\mathrm{OMe}$ & $\mathrm{OMe}$ & $\mathrm{H}$ & D & $>20$ & 3.4 & 15 & 15 & 3.8 \\
\hline
\end{tabular}

${ }^{a}$ ProQinase In-cell assay $(n=1),{ }^{b}(n=3)$

EGFR inhibitors have been used to target NSCLC and chordomas, with variation in efficacy across inhibitors and increasing resistance to inhibitors, particularly in the case of NSCLC. ${ }^{21}$ We have highlighted a series od modifications investigating the effect of key structural features on the quin(az)oline scaffold. These modifications can be used to enhance or reduce EGFR activity and generally have a pronounced effect on cellular potency.

One of the key results observed was with the removal of one the methoxy groups from 1 leading to a significant drop off in incell EGFR and anti-proliferative effects. Interestingly this is not observed in the other quinazoline and 3-cyanoquinoline templates. This was also less significant when looking at the extended aniline structure of 13-16 where the alcohol interaction with Asp855 and conformational rigidity were more significant. It was also clear that the benzyl substitution had a significant contribution to the activity despite not been in the key hinge binding interaction. The most surprising result was compound 18, which showed limited EGFR activity but the most potent anti-proliferative effect in both UCH-1 and UCH-2 chordoma cell lines. Despite some toxicity observed in WS-1 cells, $\mathbf{1 8}$ could prove to be an interesting starting point for further investigations in chordomas and NSCLC and highlights the complexity of both cancer biology and target engagement.

\section{Acknowledgments}

The SGC is a registered charity (number 1097737) that receives funds from AbbVie, Bayer Pharma AG, Boehringer Ingelheim, Canada Foundation for Innovation, Eshelman Institute for Innovation, Genome Canada, Innovative Medi-cines Initiative (EU/EFPIA) [ULTRA-DD grant no. 115766], Janssen, Merck KGaA Darmstadt Germany, MSD, Novartis Pharma AG, Ontario Ministry of Economic Development and Innovation, Pfizer, São Paulo Research Foundation-FAPESP, Takeda, and Wellcome [106169/ZZ14/Z]. We also thank CSC - IT Center for Science Ltd. Finland for the use of their facilities, software licenses and computational resources. We are grateful Dr. Brandie Ehrmann for LC-MS/HRMS support provided by the Mass Spectrometry Core Laboratory at the University of North Carolina at Chapel Hill.

\section{References and notes}

1. Cancer Fact sheet $\mathrm{N}^{\circ} 297$ WHO, 2018
2. Ferguson, F. M.; Gray, N. S. Nat Rev Drug Discov. 2018, 17, 353.

3. Lynch, T. J.; Bell, D. W.; Sordella, R.; Gurubhagavatula, S.; Okimoto, R. A.; Brannigan, B. W.; Harris, P. L.; Haserlat, S. M.; Supko, J. G.; Haluska, F. G.; Louis, D. N.; Christiani, D. C.; Settleman, J.; Haber, D. A. N. Engl. J. Med. 2004, 350, 2129.

4. Maemondo, M.; Inoue, A.; Kobayashi, K.; Sugawara, S.; Oizumi, S.; Isobe, H.; Gemma, A.; Harada, M.; Yoshizawa, H.; Kinoshita, I.; Fujita, Y.; Okinaga, S.; Hirano, H.; Yoshimori, K.; Harada, T.; Ogura, T.; Ando, M.; Miyazawa, H.; Tanaka, T.; Saijo, Y.; Hagiwara, K.; Morita, S.; Nukiwa, T. N. Engl. J. Med. 2010, 362, 2380.

5. Wood, E. R.; Truesdale, A. T.; McDonald, O. B.; Yuan, D.; Hassell, A.; Dickerson, S. H.; Ellis, B.; Pennisi, C.; Horne, E.; Lackey, K.; Alligood, K. J.; Rusnak, D. W.; Gilmer, T. M.; Shewchuk, L. Cancer Res. 2004, 64, 6652.

6. Sigismund, S.; Avanzato, D.; Lanzetti, L. Mol Oncol. 2018, 12, 3.

7. George, B.; Bresson, D.; Herman, P.; Froelich, S. Neurosurg Clin N Am. 2015, 26, 437.

8. Ferraresi, V.; Nuzzo, C.; Zoccali, C.; Marandino, F.; Vidiri, A.; Salducca, N.; Zeuli, M.; Giannarelli, D.; Cognetti, F.; Biagini, R. BMC Cancer. 2010, 28, 22.

9. Akhavan-Sigari, R.; Gaab, M.; Rohde, V.; Abili, M.; Ostertag, H. Anticancer Res. 2014, 34, 623-630.

10. Magnaghi, P.; Salom. B.; Cozzi, L.; Amboldi, N.; Ballinari, D.; Tamborini, E.; Gasparri, F.; Montagnoli, A.; Raddrizzani, L.; Somaschini, A.; Bosotti, R.; Orrenius, C.; Bozzi, F.; Pilotti, S.; Galvani, A.; Sommer, J.; Stacchiotti, S.; Isacchi, A. Mol Cancer Ther. 2018, 17, 603.

11. Scheipl, S.; Barnard, M.; Cottone, L.; Jorgensen, M.; Drewry, D. H.; Zuercher, W. J.; Turlais, F.; Ye, H.; Leite, A. P.; Smith, J. A.; Leithner, A.; Möller, P.; Brüderlein, S.; Guppy, N.; Amary, F.; Tirabosco, R.; Strauss, S. J.; Pillay, N.; Flanagan, A. M. J Pathol. 2016, 239, 320.

12. Magnaghi, P.; Salom, B.; Cozzi, L.; Amboldi, N.; Ballinari, D.; Tamborini, E.; Gasparri, F.; Montagnoli, A.; Raddrizzani, L.; Somaschini, A.; Bosotti, R.; Orrenius, C.; Bozzi, F.; Pilotti, S.; Galvani, A.; Sommer, J.; Stacchiotti, S.; Isacchi, A. Mol Cancer Ther. 2018, 17, 603 .

13. Knight, Z. A.; Shokat, K. M. Chem Biol. 2005, 12, 621.

14. Asquith, C. R. M.; Laitinen, T.; Bennett, J. M.; Godoi, P. H.; East, M. P.; Tizzard, G. J.; Graves, L. M.; Johnson, G. L.; Dornsife, R. E.; Wells, C. I.; Elkins, J. M.; Willson, T. M.; Zuercher, W. J. ChemMedChem 2018, 13, 48.

15. Asquith, C. R. M.; Berger, B.; Wan, J.; Bennett, J. M.; East, M. P.; Elkins, J. M.; Fedorov, O.; Godoi, P. H.; Hunter, D. M.; Knapp, S.; Mueller, S.; Wells, C. I.; Earp, H. S; Willson, T. M.; Zuercher, W. J. (2019) bioRxiv 376772 doi: https://doi.org/10.1101/376772

16. Fabian, M. A.; Biggs, W. H., 3rd; Treiber, D. K.; Atteridge, C. E.; Azimioara, M. D.; Benedetti, M. G.; Carter, T. A.; Ciceri, P.; Edeen, P. T.; Floyd, M.; Ford, J. M.; Galvin, M.; Gerlach, J. L.; Grotzfeld, R. M.; Herrgard, S.; Insko, D. E.; Insko, M. A.; Lai, A. G.; Lelias, J. M.; Mehta, S. A.; Milanov, Z. V.; Velasco, A. 
bioRxiv preprint doi: https://doi.org/10.1101/545525; this version posted February 11, 2019. The copyright holder for this preprint (which was not certified by peer review) is the author/funder, who has granted bioRxiv a license to display the preprint in perpetuity. It is made available under aCC-BY-NC 4.0 International license.

M.; Wodicka, L. M.; Patel, H. K.; Zarrinkar, P. P.; Lockhart, D. J. Nat Biotechnol 2005, 23, 329 .

\section{Modelling method}

Molecular modelling was performed using Schrödinger Maestro software package (Small-Molecule Drug Discovery Suite 2018-4, Schrödinger, LLC, New York, NY, 2018) Prior to docking simulations structures of small molecules were prepared using and the LigPrep module of Schrodinger suite employing OPLS3e force field. ${ }^{22}$. In the case of human EGFR there are numerous PDB structures available representing various ligand binding conformations, showing flexibility in the position of so-called the C-helix. Suitable docking templates were searched using LPDB module of Schrödinger package and carrying out visual inspection of available experimental structures with assistance of LiteMol plug-in available at website of UniProt database. Selected coordinates (PDB:3W2S) have been co-crystallized with at resolution of $1.9 \AA$ with small molecule inhibitor. ${ }^{23}$ The PDB structure of EGFR was h-bond optimized and minimized using standard protein preparation procedure of Schrödinger suite. The ligand docking was performed using SP settings of Schrodinger docking protocol with softened vdw potential (scaling 0.6), except for 7 where induced fit docking protocol was used employing standard settings. In order to improve convergence of docking poses a hydrogen bond constraint to mainchain $\mathrm{NH}$ of hinge residue M793 was required, as experimentally observed in the case of quinoline/quinolizine scaffolds. The grid box was centered using coordinate center of the core structure of corresponding x-ray ligand as template. Graphical illustrations were generated using, Maestro and PyMOL software of Schrödinger.

\section{Hydration Site Analysis}

Hydration site analysis calculated with WaterMap (Schrödinger Release 2018-4: WaterMap, Schrödinger, LLC, New York, NY, 2018.). The structure of EGFR (PDB:3W2S) was prepared with Protein Preparation Wizard (as above). ${ }^{23}$ Waters were analyzed within $6 \AA$ from the docked ligand, and the $2 \mathrm{nS}$ simulation was conducted with OPLS3e force field.

18. General procedure for the synthesis of $\mathbf{4}$-anilinoquin(az)olines: 4-chloroquin(az)oline derivative (1.0 eq.), aniline derivative (1.1 eq.), and ${ }^{\mathrm{i}} \mathrm{Pr}_{2} \mathrm{NEt}(2.5$ eq.) were suspended in ethanol $(10 \mathrm{~mL})$ and refluxed for $18 \mathrm{~h}$. The crude mixture was purified by flash chromatography using EtOAc:hexane followed by 1-5 \% methanol in EtOAc; After solvent removal under reduced pressure, the product was obtained as a free following solid or recrystallized from ethanol/water.

$\mathrm{N}$-(3-ethynylphenyl)-6,7-dimethoxyquinolin-4-amine

(1)

consistent with previous report. ${ }^{14}$

$\mathrm{N}$-(3-ethynylphenyl)-6-methoxyquinolin-4-amine (2) yellow solid $(67 \%, 237.3 \mathrm{mg}, 0.865 \mathrm{mmol}) \mathrm{MP} 195-197{ }^{\circ} \mathrm{C} ;{ }^{1} \mathrm{H}$ NMR $(400$ MHz, DMSO-d $d_{6} \delta 11.06(\mathrm{~s}, 1 \mathrm{H}), 8.43(\mathrm{~d}, J=6.8 \mathrm{~Hz}, 1 \mathrm{H}), 8.32(\mathrm{~d}$, $J=2.6 \mathrm{~Hz}, 1 \mathrm{H}), 8.06(\mathrm{~d}, J=9.3 \mathrm{~Hz}, 1 \mathrm{H}), 7.66(\mathrm{dd}, J=9.2,2.6 \mathrm{~Hz}$, $1 \mathrm{H}), 7.62$ (q, $J=1.4 \mathrm{~Hz}, 1 \mathrm{H}), 7.59-7.54(\mathrm{~m}, 2 \mathrm{H}), 7.54-7.47$ (m, $1 \mathrm{H}), 6.83(\mathrm{~d}, J=6.8 \mathrm{~Hz}, 1 \mathrm{H}), 4.34(\mathrm{~s}, 1 \mathrm{H}), 4.00(\mathrm{~s}, 3 \mathrm{H}) \cdot{ }^{13} \mathrm{C} \mathrm{NMR}$ $\left(101 \mathrm{MHz}\right.$, DMSO- $\left.d_{6}\right) \delta 158.0,153.7,140.6,137.9,133.5,130.3$, $130.3,128.3,126.0,125.5,123.2,121.9,118.6,103.1,99.8,82.6$, 82.0, 56.6. HRMS m/z $[\mathrm{M}+\mathrm{H}]^{+}$calcd for $\mathrm{C}_{18} \mathrm{H}_{15} \mathrm{~N}_{2} \mathrm{O}: 275.1184$ found $=275.1175 ; \mathrm{LC} \mathrm{t}_{\mathrm{R}}=4.46 \mathrm{~min},>98 \%$ Purity.

$\mathrm{N}$-(3-ethynylphenyl)-7-methoxyquinolin-4-amine (3) mustard solid (69\%, $244.4 \mathrm{mg}, 0.891 \mathrm{mmol}) \mathrm{MP} 282-284{ }^{\circ} \mathrm{C} ;{ }^{1} \mathrm{H}$ NMR (400 MHz, DMSO- $\left.d_{6}\right) \delta 11.06(\mathrm{~s}, 1 \mathrm{H}), 8.81(\mathrm{~d}, J=9.4 \mathrm{~Hz}, 1 \mathrm{H}), 8.42(\mathrm{~d}$, $J=7.0 \mathrm{~Hz}, 1 \mathrm{H}), 7.62-7.57(\mathrm{~m}, 1 \mathrm{H}), 7.57-7.52(\mathrm{~m}, 2 \mathrm{H}), 7.52-$ $7.43(\mathrm{~m}, 2 \mathrm{H}), 7.40(\mathrm{dd}, J=9.3,2.5 \mathrm{~Hz}, 1 \mathrm{H}), 6.72(\mathrm{~d}, J=7.0 \mathrm{~Hz}$, $1 \mathrm{H}), 4.34(\mathrm{~s}, 1 \mathrm{H}), 3.96(\mathrm{~s}, 3 \mathrm{H}) \cdot{ }^{13} \mathrm{C}$ NMR $\left(101 \mathrm{MHz}, \mathrm{DMSO}-d_{6}\right) \delta$ $163.0,154.3,142.3,140.7,137.8,130.3$ (s, 2C), 128.3, 126.1, $125.8,123.2,118.2,111.6,99.9,99.3,82.6,82.0,56.0 . \mathrm{HRMS} \mathrm{m} / \mathrm{z}$ $[\mathrm{M}+\mathrm{H}]^{+}$calcd for $\mathrm{C}_{18} \mathrm{H}_{15} \mathrm{~N}_{2} \mathrm{O}: 275.1184$ found $=275.1175 ; \mathrm{LC} \mathrm{t}_{\mathrm{R}}=$ $4.44 \mathrm{~min},>98 \%$ Purity.

$\mathrm{N}$-(3-ethynylphenyl)-6,7-dimethoxyquinazolin-4-amine

(4) colourless solid $(74 \%, 251.4 \mathrm{mg}, 0.824 \mathrm{mmol}) \mathrm{MP} 237-239^{\circ} \mathrm{C} ;{ }^{1} \mathrm{H}$ NMR $\left(500 \mathrm{MHz}\right.$, DMSO- $\left.d_{6}\right) \delta 11.48(\mathrm{~s}, 1 \mathrm{H}), 8.85(\mathrm{~s}, 1 \mathrm{H}), 8.38(\mathrm{~s}$, $1 \mathrm{H}), 7.88$ (t, $J=1.8 \mathrm{~Hz}, 1 \mathrm{H}), 7.79$ (ddd, $J=8.1,2.2,1.1 \mathrm{~Hz}, 1 \mathrm{H})$, $7.49(\mathrm{t}, J=7.8 \mathrm{~Hz}, 1 \mathrm{H}), 7.40(\mathrm{dt}, J=7.7,1.3 \mathrm{~Hz}, 1 \mathrm{H}), 7.37(\mathrm{~s}, 1 \mathrm{H})$, $4.28(\mathrm{~s}, 1 \mathrm{H}), 4.02(\mathrm{~s}, 3 \mathrm{H}), 3.99(\mathrm{~s}, 3 \mathrm{H}) .{ }^{13} \mathrm{C}$ NMR $(125 \mathrm{MHz}$, DMSO- $\left.d_{6}\right) \delta 158.1,156.3,150.2,148.8,137.4,136.0,129.2,129.2$, 127.6, 125.3, 122.0, 107.4, 104.1, 99.9, 82.9, 81.3, 57.0, 56.5. HRMS $m / z[\mathrm{M}+\mathrm{H}]^{+}$calcd for $\mathrm{C}_{18} \mathrm{H}_{16} \mathrm{~N}_{3} \mathrm{O}_{2}$ : xxxx, found 306.1230 , LC $t_{\mathrm{R}}=3.41 \mathrm{~min},>98 \%$ Purity.

$\mathrm{N}$-(3-ethynylphenyl)-6-methoxyquinazolin-4-amine (5) yellow solid (mg, mmol, \%) MP $176-178{ }^{\circ} \mathrm{C} ;{ }^{1} \mathrm{H}$ NMR $(400 \mathrm{MHz}$, DMSO- $\left.d_{6}\right) \delta 11.91(\mathrm{~s}, 1 \mathrm{H}), 8.89(\mathrm{~s}, 1 \mathrm{H}), 8.56(\mathrm{~d}, J=2.7 \mathrm{~Hz}, 1 \mathrm{H})$, $7.96(\mathrm{~d}, J=9.1 \mathrm{~Hz}, 1 \mathrm{H}), 7.92(\mathrm{t}, J=1.8 \mathrm{~Hz}, 1 \mathrm{H}), 7.83$ (ddd, $J=$ $8.1,2.2,1.2 \mathrm{~Hz}, 1 \mathrm{H}), 7.73(\mathrm{dd}, J=9.1,2.6 \mathrm{~Hz}, 1 \mathrm{H}), 7.54-7.47$ $(\mathrm{m}, 1 \mathrm{H}), 7.42(\mathrm{dt}, J=7.7,1.3 \mathrm{~Hz}, 1 \mathrm{H}), 4.29(\mathrm{~s}, 1 \mathrm{H}), 4.02(\mathrm{~s}, 3 \mathrm{H})$. ${ }^{13} \mathrm{C}$ NMR $\left(101 \mathrm{MHz}, \mathrm{DMSO}-d_{6}\right) \delta 159.2,159.0,148.8,137.1$, 133.5, 129.6, 129.1, 127.8, 127.1, 125.5, 122.0, 121.4, 114.8, 104.8, 82.9, 81.4, 56.9. HRMS m/z $[\mathrm{M}+\mathrm{H}]^{+}$calcd for $\mathrm{C}_{17} \mathrm{H}_{14} \mathrm{~N}_{3} \mathrm{O}$ : 276.1137 found $=276.1127 ; \mathrm{LC}_{\mathrm{R}}=3.47 \mathrm{~min},>98 \%$ Purity.

$\mathrm{N}$-(3-ethynylphenyl)-7-methoxyquinazolin-4-amine colourless solid $(68 \%, 240.5 \mathrm{mg}, 0.874 \mathrm{mmol}) \mathrm{MP} 223-225^{\circ} \mathrm{C} ;{ }^{\circ} \mathrm{H}$ NMR $\left(400 \mathrm{MHz}\right.$, DMSO- $\left.d_{6}\right) \delta 11.72(\mathrm{~s}, 1 \mathrm{H}), 8.96(\mathrm{~d}, J=9.3 \mathrm{~Hz}$, $1 \mathrm{H}), 8.91(\mathrm{~s}, 1 \mathrm{H}), 7.89(\mathrm{t}, J=1.9 \mathrm{~Hz}, 1 \mathrm{H}), 7.78$ (ddd, $J=8.1,2.2$, $1.2 \mathrm{~Hz}, 1 \mathrm{H}), 7.59-7.36(\mathrm{~m}, 4 \mathrm{H}), 4.29(\mathrm{~s}, 1 \mathrm{H}), 3.98(\mathrm{~s}, 3 \mathrm{H}) .{ }^{13} \mathrm{C}$ NMR (101 MHz, DMSO- $\left.d_{6}\right) \delta 164.9,159.2,150.9,141.0,137.1$, 129.5, 129.2, 127.7, 127.2, 125.4, 122.0, 119.0, 107.3, 100.2, 82.9, 81.4, 56.3. HRMS $\mathrm{m} / z[\mathrm{M}+\mathrm{H}]^{+}$calcd for $\mathrm{C}_{17} \mathrm{H}_{14} \mathrm{~N}_{3} \mathrm{O}: 276.1137$, found $276.1127, \mathrm{LC} t_{\mathrm{R}}=3.34 \mathrm{~min},>98 \%$ Purity.

4-((3-ethynylphenyl)amino)-6,7-dimethoxyquinoline-3carbonitrile (7) beige solid ( $69 \%, 228.5 \mathrm{mg}, 0.694 \mathrm{mmol}) \mathrm{MP} 241$ $243{ }^{\circ} \mathrm{C} ;{ }^{1} \mathrm{H}$ NMR $\left(400 \mathrm{MHz}\right.$, DMSO- $\left.d_{6}\right) \delta 11.46-11.29$ (s, $\left.1 \mathrm{H}\right)$, $8.98(\mathrm{~s}, 1 \mathrm{H}), 8.25(\mathrm{~s}, 1 \mathrm{H}), 7.73-7.29(\mathrm{~m}, 5 \mathrm{H}), 4.30(\mathrm{~s}, 1 \mathrm{H}), 4.00(\mathrm{~s}$, $3 \mathrm{H}), 3.99(\mathrm{~s}, 3 \mathrm{H}) .{ }^{13} \mathrm{C}$ NMR (101 MHz, DMSO- $\left.d_{6}\right) \delta 155.4,152.6$, $150.2,147.2,138.0,130.9,129.6,129.0,126.7,122.6,114.2,113.0$, 103.8, 101.4, 86.5, 82.7, 81.8, 56.9, 56.4. HRMS m/z $[\mathrm{M}+\mathrm{H}]^{+}$calcd for $\mathrm{C}_{20} \mathrm{H}_{16} \mathrm{~N}_{3} \mathrm{O}_{2}: 330.1243$ found $=330.1237$; $\mathrm{LC} \mathrm{t}_{\mathrm{R}}=4.70 \mathrm{~min}$, $>98 \%$ Purity.

4-[(3-ethynylphenyl)amino]-6-methoxyquinoline-3-carbonitrile (8) yellow solid (58 \% $198.5 \mathrm{mg}, 0.663 \mathrm{mmol}) \mathrm{MP} 245-247{ }^{\circ} \mathrm{C} ;{ }^{1} \mathrm{H}$ NMR $\left(400 \mathrm{MHz}\right.$, DMSO- $\left.d_{6}\right) \delta 11.72(\mathrm{~s}, 1 \mathrm{H}), 9.02(\mathrm{~s}, 1 \mathrm{H}), 8.40(\mathrm{~d}$, $J=2.6 \mathrm{~Hz}, 1 \mathrm{H}), 8.10(\mathrm{~d}, J=9.2 \mathrm{~Hz}, 1 \mathrm{H}), 7.72(\mathrm{dd}, J=9.2,2.6 \mathrm{~Hz}$, $1 \mathrm{H}), 7.61(\mathrm{~m}, 1 \mathrm{H}), 7.57-7.40(\mathrm{~m}, 3 \mathrm{H}), 4.31(\mathrm{~s}, 1 \mathrm{H}), 4.00(\mathrm{~s}, 3 \mathrm{H})$. ${ }^{13} \mathrm{C}$ NMR (101 MHz, DMSO-d6) $\delta$ 158.9, 153.7, 147.3, 137.7, $133.8,131.3,129.6,129.3,127.0,126.2,123.3,122.6,120.0,114.1$, $104.3,86.6,82.7,81.8,56.8$. HRMS $\mathrm{m} / \mathrm{z}[\mathrm{M}+\mathrm{H}]^{+}$calcd for $\mathrm{C}_{19} \mathrm{H}_{14} \mathrm{~N}_{3} \mathrm{O}: 300.1137$ found $=300.1135 ; \mathrm{LC} \mathrm{t}_{\mathrm{R}}=4.90 \mathrm{~min},>98 \%$ Purity.

4-[(3-ethynylphenyl)amino]-7-methoxyquinoline-3-carbonitrile (9) yellow solid (62\%,212.2 mg, $0.708 \mathrm{mmol}, \%)$ MP $245-247{ }^{\circ} \mathrm{C}$, ${ }^{1} \mathrm{H}$ NMR (400 MHz, DMSO-d $\left.d_{6}\right) \delta 11.67$ (s, $\left.1 \mathrm{H}\right), 9.06(\mathrm{~s}, 1 \mathrm{H}), 8.88$ $(\mathrm{d}, J=9.4 \mathrm{~Hz}, 1 \mathrm{H}), 7.75-7.28(\mathrm{~m}, 6 \mathrm{H}), 4.31(\mathrm{~s}, 1 \mathrm{H}), 3.98(\mathrm{~s}, 3 \mathrm{H})$. ${ }^{13} \mathrm{C}$ NMR (101 MHz, DMSO- $\left.d_{6}\right) \delta 164.0,154.1,149.8,141.0$, 137.6, 131.3, 129.6, 129.3, 127.1, 126.7, 122.6, 119.0, 114.0,112.6, $101.7,86.2,82.7,81.8,56.3$. HRMS $\mathrm{m} / \mathrm{z}[\mathrm{M}+\mathrm{H}]^{+}$calcd for $\mathrm{C}_{19} \mathrm{H}_{13} \mathrm{~N}_{3} \mathrm{O}: 300.1137$ found $=300.1130 ; \mathrm{LC} \mathrm{t}_{\mathrm{R}}=4.40 \mathrm{~min},>98 \%$ Purity.

$N$-\{4-[(6,7-dimethoxyquinolin-4-yl)amino]-2-hydroxyphenyl\}4-methylbenzamide (13) as a colorless solid $(85 \%, 151 \mathrm{mg}, 0.351$ mmol) decomposed $>280{ }^{\circ} \mathrm{C} ;{ }^{1} \mathrm{H}$ NMR $\left(400 \mathrm{MHz}\right.$, DMSO- $\left.d_{6}\right) \delta$ $10.58(\mathrm{~s}, 1 \mathrm{H}), 10.46(\mathrm{~s}, 1 \mathrm{H}), 9.53(\mathrm{~s}, 1 \mathrm{H}), 8.35(\mathrm{~d}, J=6.9 \mathrm{~Hz}, 1 \mathrm{H})$, $8.12(\mathrm{~s}, 1 \mathrm{H}), 7.91(\mathrm{~d}, J=8.3 \mathrm{~Hz}, 2 \mathrm{H}), 7.44(\mathrm{~s}, 1 \mathrm{H}), 7.35(\mathrm{~d}, J=8.0$ $\mathrm{Hz}, 2 \mathrm{H}), 7.07(\mathrm{~d}, J=2.4 \mathrm{~Hz}, 1 \mathrm{H}), 6.94(\mathrm{dd}, J=8.5,2.4 \mathrm{~Hz}, 1 \mathrm{H})$, $6.77(\mathrm{~d}, J=6.9 \mathrm{~Hz}, 1 \mathrm{H}), 3.99(\mathrm{~d}, J=11.8 \mathrm{~Hz}, 6 \mathrm{H}), 2.40(\mathrm{~s}, 3 \mathrm{H}) .{ }^{13} \mathrm{C}$ NMR $\left(101 \mathrm{MHz}\right.$, DMSO-d $\left.d_{6}\right) \delta 165.1,154.6,153.2,150.1,149.4$, $141.8,139.8,135.3,134.3,131.4,129.1$ (s, 2C), 127.6 (s, 2C), $125.1,124.5,115.8,112.8,111.5,102.6,99.9,99.2,56.7,56.2$, 21.0. HRMS m/z $[\mathrm{M}+\mathrm{H}]^{+}$calcd for $\mathrm{C}_{25} \mathrm{H}_{24} \mathrm{~N}_{3} \mathrm{O}_{4}: 430.1767$ found $=$ $430.1751 ; \mathrm{LC} \mathrm{t}_{\mathrm{R}}=4.46 \mathrm{~min},>98 \%$ Purity.

$\mathrm{N}$-(2-hydroxy-4-((6-methoxyquinolin-4-yl)amino)phenyl)-4-

methylbenzamide (14) as a yellow solid $(56 \%, 89 \mathrm{mg}, 0.232$ mmol) decomposed $>280{ }^{\circ} \mathrm{C} ;{ }^{1} \mathrm{H}$ NMR $\left(500 \mathrm{MHz}\right.$, DMSO- $\left.d_{6}\right) \delta$ $10.73(\mathrm{~s}, 1 \mathrm{H}), 10.49(\mathrm{~s}, 1 \mathrm{H}), 9.54(\mathrm{~s}, 1 \mathrm{H}), 8.43(\mathrm{~d}, J=6.8 \mathrm{~Hz}, 1 \mathrm{H})$, $8.19(\mathrm{~d}, J=2.6 \mathrm{~Hz}, 1 \mathrm{H}), 8.01(\mathrm{~d}, J=9.2 \mathrm{~Hz}, 1 \mathrm{H}), 7.92(\mathrm{dd}, J=8.4$, $6.8 \mathrm{~Hz}, 3 \mathrm{H}), 7.66(\mathrm{dd}, J=9.3,2.6 \mathrm{~Hz}, 1 \mathrm{H}), 7.35(\mathrm{~d}, J=8.0 \mathrm{~Hz}, 2 \mathrm{H})$, $7.09(\mathrm{~d}, J=2.4 \mathrm{~Hz}, 1 \mathrm{H}), 6.96(\mathrm{dd}, J=8.5,2.4 \mathrm{~Hz}, 1 \mathrm{H}), 6.84(\mathrm{~d}, J=$ $6.8 \mathrm{~Hz}, 1 \mathrm{H}), 3.99(\mathrm{~s}, 3 \mathrm{H}), 2.40(\mathrm{~s}, 3 \mathrm{H}) \cdot{ }^{13} \mathrm{C}$ NMR $(126 \mathrm{MHz}$, DMSO- $\left.d_{6}\right) \delta 165.1,158.0,153.8,150.2,141.8,140.7,134.1,133.6$, $131.4,129.1$ (s, 2C), 127.6 (s, 2C), 125.3, 125.2, 124.6, 122.1, $118.4,115.8,112.8,102.8,99.6,56.5,21.0$. HRMS m/z $[\mathrm{M}+\mathrm{Na}]^{+}$ calcd for $\mathrm{C}_{24} \mathrm{H}_{21} \mathrm{~N}_{3} \mathrm{O}_{3} \mathrm{Na}: 422.1481$ found $=422.1185 ; \mathrm{LC} \mathrm{t}_{\mathrm{R}}=4.23$ min, $>98 \%$ Purity.

$\mathrm{N}$-(2-hydroxy-4-((7-methoxyquinolin-4-yl)amino)phenyl)-4methylbenzamide (15) as a yellow solid $(67 \%, 111 \mathrm{mg}, 0.278$ mmol) decomposed $>270{ }^{\circ} \mathrm{C} ;{ }^{1} \mathrm{H}$ NMR $\left(500 \mathrm{MHz}\right.$, DMSO- $\left.d_{6}\right) \delta$ $9.92(\mathrm{~s}, 1 \mathrm{H}), 9.46(\mathrm{~s}, 1 \mathrm{H}), 8.83(\mathrm{~s}, 1 \mathrm{H}), 8.39(\mathrm{~d}, J=5.3 \mathrm{~Hz}, 1 \mathrm{H})$, $8.28(\mathrm{~d}, J=9.3 \mathrm{~Hz}, 1 \mathrm{H}), 8.06-7.79(\mathrm{~m}, 2 \mathrm{H}), 7.66(\mathrm{~d}, J=8.5 \mathrm{~Hz}$, $1 \mathrm{H}), 7.34(\mathrm{~d}, J=8.0 \mathrm{~Hz}, 2 \mathrm{H}), 7.25(\mathrm{~d}, J=2.7 \mathrm{~Hz}, 1 \mathrm{H}), 7.16(\mathrm{dd}, J$ $=9.2,2.7 \mathrm{~Hz}, 1 \mathrm{H}), 6.92(\mathrm{~d}, J=2.4 \mathrm{~Hz}, 1 \mathrm{H}), 6.87-6.67(\mathrm{~m}, 2 \mathrm{H})$, $3.90(\mathrm{~s}, 3 \mathrm{H}), 2.39(\mathrm{~s}, 3 \mathrm{H}) .{ }^{13} \mathrm{C} \mathrm{NMR}\left(126 \mathrm{MHz}, \mathrm{DMSO}-d_{6}\right) \delta 165.1$, $159.9,150.9,150.8,150.2,147.7,141.6,138.2,131.5,129.0(\mathrm{~s}$, 2C), 127.5 (s, 2C), 124.9, 123.5, 121.8, 116.5, 114.3, 113.1, 109.9, 
bioRxiv preprint doi: https://doi.org/10.1101/545525; this version posted February 11, 2019. The copyright holder for this preprint (which was not certified by peer review) is the author/funder, who has granted bioRxiv a license to display the preprint in perpetuity. It is made available under aCC-BY-NC 4.0 International license.

107.8, 100.6, 55.3, 21.0. HRMS m/z $[\mathrm{M}+\mathrm{H}]^{+}$calcd for $\mathrm{C}_{24} \mathrm{H}_{22} \mathrm{~N}_{3} \mathrm{O}_{3}$ : 400.1661 found $=400.1647 ; \mathrm{LC}_{\mathrm{R}}=4.21 \mathrm{~min},>98 \%$ Purity.

$N$-(4-((6,7-dimethoxyquinolin-4-yl)amino)phenyl)-4methylbenzamide mustard solid (16) 4-chloro-6,7dimethoxyquinoline (200 $\mathrm{mg}, 0.89 \mathrm{mmol})$ and $\mathrm{N}$-(4-aminophenyl)4-methylbenzamide (222.6 mg, $0.98 \mathrm{mmol}) \mathrm{Pd}_{2}(\mathrm{dba})_{3}(122.8 \mathrm{mg}$, $0.13 \mathrm{mmol})$, XPhos (64 $\mathrm{mg}, 0.13 \mathrm{mmol})$ and caesium carbonate (874 $\mathrm{mg}, 2.68 \mathrm{mmol}$ ) were all suspended in DMF $15 \mathrm{~mL}$ and degassed for $5 \mathrm{~min}$. The mixture was held at reflux at $140^{\circ} \mathrm{C}$ for 18 h. The crude mixture was then passed through a plug of celite 545 before been purified by flash chromatography $20-100 \%$ EtOAc:hexane followed by 1-5\% methanol/ethyl acetate and solvent removed under reduced pressure to yield the product as a free following solid: $(72 \%, 266 \mathrm{mg}, 0.64 \mathrm{mmol}) 122-125{ }^{\circ} \mathrm{C}{ }^{1} \mathrm{H}$ NMR $\left(400 \mathrm{MHz}\right.$, DMSO- $\left.d_{6}\right) \delta 10.20(\mathrm{~s}, 1 \mathrm{H}), 8.68(\mathrm{~s}, 1 \mathrm{H}), 8.26(\mathrm{~d}$, $J=5.3 \mathrm{~Hz}, 1 \mathrm{H}), 8.09-7.72(\mathrm{~m}, 4 \mathrm{H}), 7.69(\mathrm{~s}, 1 \mathrm{H}), 7.63-7.26(\mathrm{~m}$, $4 \mathrm{H}), 7.24(\mathrm{~s}, 1 \mathrm{H}), 6.73(\mathrm{~d}, J=5.3 \mathrm{~Hz}, 1 \mathrm{H}), 3.92(\mathrm{~d}, J=13.4 \mathrm{~Hz}$, $6 \mathrm{H}), 2.40(\mathrm{~s}, 3 \mathrm{H}) .{ }^{13} \mathrm{C}$ NMR $\left(101 \mathrm{MHz}\right.$, DMSO- $\left.d_{6}\right) \delta 165.6,152.0$, $148.6,148.5,147.4,146.1,141.9,136.6,135.7,132.6,129.4(\mathrm{~s}$, 2C), 128.1 (s, 2C), 123.6 (s, 2C), $121.8(\mathrm{~s}, 2 \mathrm{C}), 114.1,108.6,101.4$, 100.7, 56.4, 55.9, 21.5. HRMS m/z $[\mathrm{M}+\mathrm{H}]^{+}$calcd for $\mathrm{C}_{25} \mathrm{H}_{24} \mathrm{~N}_{3} \mathrm{O} 3$ : 414.1818 found $=414.1808 ; \mathrm{LC} \mathrm{t}_{\mathrm{R}}=5.05 \mathrm{~min},>98 \%$ Purity.

4-(tert-butyl)- $N$-(4-((6,7-dimethoxyquinolin-4-yl)amino)-2-

hydroxyphenyl)benzamide (17) as a bright yellow solid (68\%, $103 \mathrm{mg}, 0.218 \mathrm{mmol}$ ) decomposed $>260{ }^{\circ} \mathrm{C} ;{ }^{1} \mathrm{H}$ NMR $(400 \mathrm{MHz}$, DMSO-d $\left.d_{6}\right) 10.62(\mathrm{~s}, 1 \mathrm{H}), 10.49(\mathrm{~s}, 1 \mathrm{H}), 9.53(\mathrm{~s}, 1 \mathrm{H}), 8.34(\mathrm{~d}, J=$ $7.0 \mathrm{~Hz}, 1 \mathrm{H}), 8.14(\mathrm{~s}, 1 \mathrm{H}), 7.94(\mathrm{~d}, J=7.2 \mathrm{~Hz}, 2 \mathrm{H}), 7.56(\mathrm{~d}, J=8.0$ $\mathrm{Hz}, 1 \mathrm{H}), 7.45$ (s, 1H), 7.08 (s, 1H), 6.94 (d, $J=8.5 \mathrm{~Hz}, 1 \mathrm{H}), 6.76$ $(\mathrm{d}, J=6.8 \mathrm{~Hz}, 1 \mathrm{H}), 3.99(\mathrm{~d}, J=14.2 \mathrm{~Hz}, 6 \mathrm{H}), 1.32(\mathrm{~s}, 9 \mathrm{H}) .{ }^{13} \mathrm{C}$ NMR $\left(101 \mathrm{MHz}\right.$, DMSO- $\left.d_{6}\right) \delta 165.1,154.7,154.5,153.2,150.0$, $149.4,139.7,135.3,134.2,131.5,127.4$ (s, 2C), 125.3 (s, 2C), $125.1,124.3,115.8,112.8,111.5,102.7,99.9,99.2,56.7,56.1$, $34.7,30.9$ (s, 3C). HRMS m/z $[\mathrm{M}+\mathrm{H}]^{+}$calcd for $\mathrm{C}_{28} \mathrm{H}_{30} \mathrm{~N}_{3} \mathrm{O}_{4}$ : 472.2236 found $=472.2218 ; \mathrm{LC} \mathrm{t}_{\mathrm{R}}=5.15 \mathrm{~min},>98 \%$ Purity. 6,7-dimethoxy- $\mathrm{N}$-(4-((4-methylbenzyl)oxy)phenyl)quinolin-4amine (18) as a light yellow/cyan solid $(74 \%, 126 \mathrm{mg}, 0.315$ mmol) $158-160{ }^{\circ} \mathrm{C} ;{ }^{1} \mathrm{H}$ NMR $\left(400 \mathrm{MHz}\right.$, DMSO- $\left.d_{6}\right) \delta 10.62(\mathrm{~s}, 1 \mathrm{H})$, $8.29(\mathrm{~d}, J=7.0 \mathrm{~Hz}, 1 \mathrm{H}), 8.15(\mathrm{~s}, 1 \mathrm{H}), 7.45(\mathrm{~s}, 1 \mathrm{H}), 7.37$ (dd, $J=$ $8.5,2.5 \mathrm{~Hz}, 4 \mathrm{H}), 7.29-7.04(\mathrm{~m}, 4 \mathrm{H}), 6.55(\mathrm{~d}, J=6.9 \mathrm{~Hz}, 1 \mathrm{H}), 5.11$ (s, 2H), 3.99 (s, 3H), $3.96(\mathrm{~s}, 3 \mathrm{H}), 2.32(\mathrm{~s}, 3 \mathrm{H}) .{ }^{13} \mathrm{C}$ NMR $(101 \mathrm{MHz}$, DMSO- $\left.d_{6}\right) \delta 157.3,154.5,153.6,149.3,139.8,137.2,135.3,133.8$, $130.1,129.0$ (s, 2C), 127.9 (s, 2C), $127.2(\mathrm{~s}, 2 \mathrm{C}), 115.9$ (s, 2C), $111.3,102.7,99.9,98.8,69.5,56.7,56.1,20.8 . \mathrm{HRMS} \mathrm{m} / \mathrm{z}[\mathrm{M}+\mathrm{H}]^{+}$ calcd for $\mathrm{C}_{25} \mathrm{H}_{25} \mathrm{~N}_{2} \mathrm{O}_{3}$ : 401.1865 found $=401.1849 ; \mathrm{LC}_{\mathrm{R}}=5.16$ $\min ,>98 \%$ Purity.

$\mathrm{N}$-(4-((6,7-dimethoxyquinolin-4-yl)amino)phenyl)acetamide

(19) as a grey solid ( $77 \%, 144 \mathrm{mg}, 0.427 \mathrm{mmol})$ decomposed $>260$ ${ }^{\circ} \mathrm{C}$ HRMS m/z $[\mathrm{M}+\mathrm{H}]^{+}$calcd for $\mathrm{C}_{19} \mathrm{H}_{20} \mathrm{~N}_{3} \mathrm{O}_{3}: 338.1505$ found $=$ $338.1489 ; L_{C} t_{R}=3.09 \mathrm{~min},>98 \%$ Purity. Consistent with previous report ${ }^{24}$

\section{Cell Culture Biology Method}

Chordoma cell lines UCH-1 and UCH-2 were cultured in $4: 1$ IMDM:RPMI supplemented with $10 \%$ Fetal Bovine Serum $1 \%$ Penicillin/Streptomycin in gel-coated flasks. WS-1 and A-431 cells were cultured in DMEM supplemented with $10 \%$ Fetal Bovine Serum $1 \%$ Penicillin/Streptomycin. UCH-1 and UCH-2 were seeded at 250 cells/well in gel-coated 384 well plates. WS-1 cells were seeded at 400 cells/well in 384 well plates, and A-431 cells were seeded at 500 cells/well in 384 well plates. Cells were treated with compound at $24 \mathrm{~h}$ after plating and cell viability was assessed at $72 \mathrm{~h}$ using alamarBlue (ThermoFisher, USA). Fluorescence was measured using Tecan infinite 200 plate with excitation at $535 \mathrm{nM}$ and emission at $590 \mathrm{nM}$. $\mathrm{IC}_{50}$ values were determined by nonlinear regression using Graphpad Prism ${ }^{\mathrm{TM}}$ software.

19. Asquith, C. R. M.; Naegeli, K. M.; East, M. P.; Laitinen, T.; Havener, T. M.; Wells, C. I.; Johnson, G. L.; Drewry, D. H.; Zuercher, W. J.; Morris, D. C. (2019) bioRxiv 475251 doi: https://doi.org/10.1101/475251

20. Compound 13 CCDC number 1894101

21. Engel, J.; Smith, S.; Lategahn, J.; Tumbrink, H. L.; Goebel, L.; Becker, C.; Hennes, E.; Keul, M.; Unger, A.; Müller, H.; Baumann, M.; Schultz-Fademrecht, C.; Günther, G.; Hengstler, J. G.; Rauh, D. J Med Chem. 2017, 60, 7725.

22. 22 Harder, E.; Damm, W.; Maple, J.; Wu, C.; Reboul, M.; Xiang, J. Y.; Wang, L.; Lupyan, D.; Dahlgren, M. K.; Knight, J. L.; Kaus, J. W.; Cerutti, D. S.; Krilov, G.; Jorgensen, W. L.; Abel, R.; Friesner, R. A. J Chem Theory Comput. 2016, 12, 281.
23. 23 Sogabe, S.; Kawakita, Y.; Igaki, S.; Iwata, H.; Miki, H.; Cary, D. R.; Takagi, T.; Takagi, S.; Ohta, Y.; Ishikawa, T. ACS Med Chem Lett. 2012, 4, 201.

24. Kubo, K.; Shimizu, T.; Ohyama, S.; Murooka, H.; Iwai, A.; Nakamura, K.; Hasegawa, K.; Kobayashi, Y.; Takahashi, N.; Takahashi, K.; Kato, S.; Izawa, T.; Isoe, T. J Med Chem. 2005, 48, 1359.

\section{Supplementary Material}

Supplementary material 